\title{
Tests of Writing Competence at Ontario Universities
}

\author{
DAVID PALMER*
}

\begin{abstract}
Over the last ten years some Ontario universities have introduced post-admission or "exit" writing proficiency requirements which their students must eventually satisfy. These requirements reflect a concern about admission standards and tests which goes back more than twenty years and which has focussed primarily on language skills. The writing tests are intended to identify students likely to encounter academic difficulties because of poor writing skills, but the usual rationale for the tests rests upon dubious assumptions, and the nature of some of the test procedures makes it difficult to know whether the objectives of the tests are being met.
\end{abstract}

\section{RÉSUMÉ}

Pendant ces dix dernières années, des universités ontariennes ont introduit des tests de compétence en l'art d'écrire, tests de postadmission ou de "sortie", auxquels leurs étudiants doivent finalement réussir. Les tests reflètent une inquiétude concernant les niveaux voulus et les tests d'admission; une inquiétude qui dure depuis plus de vingt ans et qui s'est surtout concentrée sur les compétences linguistiques. Le but des tests est d'identifier les étudiants susceptibles d'éprouver des difficultés scolaires à cause de leur maitrise inadéquate de l'art d'écrire. La raison d'être habituelle de ces tests repose, cependant, sur des suppositions contestables, et la nature de quelques-uns des procédés employés le rend difficile de savoir si on atteint les objectifs déclarés.

The controversy which followed the introduction of a compulsory writing test for new students at McMaster University in September 1986 revealed that suggestions of student "illiteracy" continue to make headlines. The originally announced failure rate of $42 \%$ (later reduced to $27 \%$ on discovery of an error in scoring) was, for the press, yet another allegation about the inadequacy of the schools. 
University staff were invited to make judgments about the teaching of English in secondary schools, and school administrators defended themselves against a presumed attack. The events recalled similar controversies in the 1970's, especially that which followed the introduction of a writing test at the University of Waterloo in 1976. The McMaster situation was further complicated by the university's use of an entirely multiple-choice test of writing ability. Such a procedure has been traditionally regarded by English teachers with the deepest suspicion, though their objections have been repeatedly challenged (Palmer, 1987). McMaster was in fact only the latest of several Ontario universities to introduce a post-admission writing test, and the introduction of these tests reflects a long-standing concern about admission standards and testing. The revival of the controversy offers an opportunity to set this latest move in its historical context, and to reconsider the purpose and usefulness of such tests.

The most useful way of describing the historical context of the present situation is to look at certain changes that occurred in university admission procedures in Ontario in the mid-sixties. Discussions about the possibility of setting up a Canadian organization to administer university admission tests began in 1962 , with consultations between the National Conference of Canadian Universities and Colleges (forerunner of the present Association of Universities and Colleges of Canada) and two American organizations, the College Entrance Examination Board and the Educational Testing Service. By 1965 a detailed proposal for such a scheme had been worked out by the NCCUC jointly with the Standing Committee of Ministers of Education of the Provinces of Canada, and as a result the Service for Admission to College and University (SACU) was set up in 1966. It did not administer its first tests, however, until 1969 (Elliott, 1971). Meanwhile in Ontario the dramatic increase in the numbers of students heading for postsecondary education was putting great strains on provincial examination procedures. The Grade 13 Study Committee (Report, 1964) set up by the Minister of Education, William Davis, recommended that the weighting of the Ontario Department of Education examinations in determining marks should be gradually reduced in favour of teacher-assigned grades, and that for the purpose of university admission these marks should eventually be supplemented by the proposed Canadian aptitude and achievement tests. In accordance with the committee's recommendation, grade 13 scores from June 1965 included teacher marks as a minority component. In 1966 Davis pre-empted the proposed gradual reduction of the importance of the provincial examinations by announcing that they would be written for the last time in June 1967. Davis also announced that "the newly formed Canadian Service for Admission to College and University" would administer "scholastic aptitude and achievement tests...similar to the ones which have been used in the United States for more than thirty years" (Building an Educated Society, 1966, p. 7).

Due to the delay in getting SACU's tests started, Ontario tests were developed at the recently formed Ontario Institute for Studies in Education at Davis's request and administered in 1967 and 1968 as the Ontario Tests for Admission to College 
and University (Elliott, 1971). These objective tests, which followed the designs of the College Board examinations in the United States, included the Ontario Scholastic Aptitude Test (yielding verbal and quantitative scores), tests of mathematics and physics, and the Ontario English Composition Achievement Test, later known perhaps in deference to criticisms that it contained no actual composition - as the Ontario Standard English Achievement Test. Applicants to Ontario universities were encouraged or required to submit their marks on some or all of these tests in addition to their grade 13 marks. The English versions of the Canada-wide SACU tests were also developed at O.I.S.E., simplifying the transition to a national testing system in 1969, when the Canadian Scholastic Aptitude Test and the Canadian English Language Achievement Test took over from their Ontario forerunners (Elliott, 1971; D’Oyley \& Müller-Solger, 1975). Tests of mathematics and physics, however, were not included among the SACU tests, and the Ontario tests in these subjects were last administered in 1970 (Secondary/Postsecondary Interface Study, 1976, Project II, vol. 1, p. 7).

In its early years SACU set up overseas as well as domestic test centres and planned a significant expansion of activities, including the development of a mathematics test and tests for guidance purposes (Elliott, 1971). But a study committee on SACU which reported in 1973 found the organization "very close to dissolution" in view of a growing philosophy of open admission to universities, opposition to the tests in the school system, resentment against American styles of assessment, and uneven support from the various provincial ministries of education (D'Oyley \& Müller-Solger, 1975). In the early seventies universities seem to have found that they were not significantly using the SACU scores in admission decisions, and it appears that there was not a strong desire, in view of concerns about stagnating or declining enrolments and their impact on funding, to retain them as admission requirements. In addition, studies had shown that the tests were not as useful as teachers' marks in predicting university performance (Khan, Ransom \& Herbert, 1970; Khan \& Rickard, 1971). The numbers of students writing the SACU tests reached their peak in 1971 and declined thereafter. The decisive factor appears to have been the decision of the Ontario Ministry of Education in 1972 to discontinue paying the costs of administering the tests in Ontario, which necessitated the imposition of test fees for Ontario students. SACU was eventually wound up in 1974.

By a process of default the Ontario universities had arrived at a position that had probably not been envisaged by the various interested parties. The universities confronted a steady rise in the number of supposedly qualified applicants, but lacked any standard entrance examinations to help them determine whether applicants were in fact well prepared for university, in view of possible changes in marking standards and the impact of the new secondary school credit system. The discontinuation of the grade 13 examinations in 1967 had in fact been followed by an immediate increase of almost $40 \%$ in the proportion of grade 13 students qualifying for university admission by obtaining an average of at least $60 \%$, and a continuing trend in the same direction thereafter (Watson \& Quazi, 1969; D'Oyley 
\& Müller-Solger, 1975). It was largely concern about the lack of control over admission standards that led to a joint "policy review" by the Ministry of Education and the Ministry of Colleges and Universities, resulting in the large-scale Secondary/Postsecondary Interface Study of 1975-76. The Council of Ontario Universities, in its brief to the policy review group, recommended the introduction or re-introduction of uniform achievement tests in English and - for those taking the subject in grade 13 - mathematics. The Council has continued to mention its support of this idea on subsequent occasions when the universities have been consulted about secondary school graduation requirements. It carried out experimental testing in several universities in September 1975 and 1976, using tests of English and (in the first year only) mathematics, and in 1979 set up a committee on post-admission testing which has overseen the development of tests of English for native speakers (the Ontario Test of English Achievement) and foreign students (the Ontario Test of English as a Second Language).

English language skills seem to have been the main focus of a wider concern in the universities about admission standards and testing, and the most obvious manifestation of those language skills, both to university teachers and subsequently to employers, is the writing that students and graduates produce. If reading ability were as easily noticed it might well have become an equal subject of concern. The "literacy" of high school graduates, as evidenced in their writing, was a hot press topic in 1975 and the following few years. "Complaints about illiteracy among high school graduates," the Globe and Mail editorialized on July 9, 1976, "have been heard, with compelling frequency, from a wide range of sources: the Canadian Chamber of Commerce, the Ontario Secondary School Teachers' Federation, the Association of Canadian University Teachers of English and lone academics from coast to coast." In 1975 the Colleges of Applied Arts and Technology, citing widespread concerns about student "illiteracy", embarked on the development of a uniform language test, a project which was finally completed in 1983 (Northey \& Evans, 1983). In 1976 the Association of Canadian University Teachers of English produced two reports partly or wholly dealing with dissatisfaction about students' capacities to write (Fleck, 1976; Priestley \& Kerpneck, 1976). The Association's president called for the development of a national English test "upon which universities, colleges and employers may rely for assurance that those who seek admission or employment have learned the basic skills of language" (Globe \& Mail, April 2, 1976). In the same year a widely-publicised report claimed the existence of a crisis of "literacy" among students at Queen's University (Norman, 1976). An opinion survey carried out in 1975 as part of the Secondary/Postsecondary Interface Study (1976, Summary Report, pp. 14-15) found that about $70 \%$ of secondary school, college and university teachers felt that the basic language skills of their students had deteriorated. The same proportion of both students and the general public said that there was not enough emphasis on reading and writing skills in secondary schools. 
Despite this general concern the re-introduction of university entrance tests in Ontario in the mid-seventies seemed rather unlikely. Ministry of Education policy appeared set in the direction of decentralization of evaluation, with the ministry's role focussing on such activities as the issuing of new curriculum guidelines and the development of the Ontario Assessment Instrument Pool, which consists of assessment materials for optional use by schools or boards of education. Universities, meanwhile, showed few signs of willingness to undertake initiatives which might jeopardise levels of enrolment. The attention of administrators at some universities therefore turned to the idea of post-admission and "exit" writing tests, which students would be required to pass in order to continue in a program or to graduate. The University of Waterloo was the first university in Ontario to establish such a requirement, and by 1977 new students in most faculties there had to pass Waterloo's English Language Proficiency Examination before graduating. The University of Toronto adopted a somewhat similar requirement in 1980 , shortly before planning the much greater step of instituting its own range of admission tests, a plan that was later abandoned. The English proficiency test at Toronto was discontinued as of September 1987 for budgetary reasons. The University of Guelph instituted a writing test in 1982 and McMaster in 1986. Some other universities in Ontario, or sections within universities, have required or encouraged entering students to take writing tests to determine placement in writing courses or simply to identify students likely to encounter problems with writing. Meanwhile, similar developments have been occurring throughout Canada. About half of the universities responding to a nationwide survey in 1984 administered writing tests of some kind to incoming students, and in several universities outside Ontario it was not possible to graduate from at least some faculties without demonstrating writing proficiency (Drain, 1984). In step with this development has been a rapid growth in the number of credit writing courses, along with writing centres, "labs", "clinics" and so forth. Other university initiatives aimed at dealing with the problem have included changes in admission or degree requirements to make school or university English credits compulsory, the imposition of higher minimum scores on language tests for foreign students, and the elimination of exemptions from those language tests for foreign students who have attended Ontario secondary schools. The introduction of writing tests as a graduation or program requirement represents the most radical of a series of measures which reflect dissatisfaction about the level of students' proficiency in English.

Among the four Ontario universities which have made the demonstration of proficiency in writing a more or less universal requirement there are significant differences in the kinds of tests, the consequences of failing, and the remedial opportunities offered. At Waterloo students are required to write an essay (under test conditions), although a multiple-choice test was included during the first few years. Toronto's test also consisted simply of an essay until its recent abandon- 
ment; a summary of a set passage was planned originally as part of the test, but proved too difficult to score. The University of Guelph uses the Ontario Test of English Achievement, which consists of an essay and three objective tests of reading comprehension, "thesis development" and "language". McMaster uses an objective test derived from the English tests used for admission purposes in Canadian universities in the early seventies, as mentioned earlier. At Waterloo, passing the test is a graduation requirement in most faculties. Students who fail must re-write the test, and can use a tutorial centre, without charge, to help them prepare to do this. At Toronto, students were required to satisfy the writing proficiency requirement within two years of entry. Those who failed the test could re-write, or they could satisfy the requirement by passing a partially subsidized non-credit course. A special version of this course was available for students whose native language was not English. At Guelph, students who have not passed the test have a notation to this effect placed on their transcripts, but as long as they at least attempt the test their eventual graduation is not blocked. If they fail the test twice, however, they must take a non-credit course offered for the university by the local board of education. There is a modest fee for this course. Passing the course clears the transcript notation. A notation on the transcripts of students who have not passed the university's writing test is also made at McMaster, but some faculties have introduced additional requirements which prevent students who have not passed the test from proceeding beyond a certain point in their programs. Students may re-write the test free of charge as many times as they wish. A remedial course intended to help them pass the course is offered but is not significantly subsidized and is therefore rather expensive. Passing it does not exempt students from the writing test requirement. McMaster has recently decided to exempt from the test students with grade 13 English marks of $80 \%$ and above.

What is the purpose of the tests? Some of the administrators of university writing tests responding to Drain's (1984) survey commented that testing simply raised student awareness about the importance of good writing and the universities' expectations of them in that respect. But with regard to the universities I am concerned with here, the general impression seems to be that the compulsory test requirement is intended to identify at an early stage students who are likely to have difficulty in completing academic requirements because of poor writing ability, and to require them, in their own interest, to do something to head off these problems. The University of Waterloo, for example, cites "concern that some students encounter academic difficulties because they lack the basic writing skills required for university work" as the reason for instituting its writing test program (English Language Proficiency Program, p. 1). The assumptions underlying this notion appear to be that students with poor writing skills are not likely to succeed in many university courses, that it is easier for such students to do something about their writing ability in advance than to wait until it causes them problems in their courses, and that it is possible for students to improve their writing significantly in a fairly short period of time. All these assumptions, however, may well be unjustified. 
Language tests have shown themselves to be rather poor predictors of success in university. Correlations between scores on individual tests of language and overall first-year university averages tend to range up to about 0.35 . Overall grade 13 marks in Ontario, by contrast, tend to show correlations in excess of 0.6 with university grades. The Atkinson Study of Utilization of Student Resources found that verbal aptitude test scores were not a useful predictor of university performance (although better for arts students than for those in science) and that a standard reading test had virtually no value in this respect. Grade 13 scores, on the other hand, tended to be as good predictors of first-year averages as first-year marks were of performance in the later university years (Fleming, 1965, 1969). Khan and Rickard (1971) found a correlation of about 0.35 between performance on the Ontario Standard English Achievement Test and overall first-year university marks for students in all major disciplines. The Ontario Scholastic Aptitude Test verbal score predicted less well. The University of Waterloo found that correlations between scores on its writing proficiency test and first-year marks ranged from zero to 0.3 (Notes Toward a History, 1977, p. 18). The Ontario Test of English Achievement produced correlations of about 0.35 between performance on the whole test and first-year university averages. The Grade 13 averages for the same students, by contrast, showed a correlation of 0.62 with overall university marks (OTEA, 1983, p. 19).

These results suggest that language proficiency is only one of many factors affecting success at university, even in verbally based disciplines. University results, like high school marks, are usually based on an aggregate of scores achieved on a variety of different tasks. It is difficult to conclude that even a fairly severe problem in one area, such as writing, will necessarily preclude at least modest success for a student, and we will probably look in vain for a language test that shows a strong relationship with overall university performance. Students can often get through university courses without having the degree of skill in writing that their teachers expect, and this in fact seems to be why the writing tests have been called for. It would of course be possible to deny students passing marks in many courses solely on the grounds of writing ability, but in practice there appears to be an understandable reluctance among faculty members to do so when their prime concern is to assess students' grasp of discipline-specific subject matter. Except in courses specifically designed to teach writing, it appears that most professors are unwilling to fail students simply because of weakness in an ancillary aspect of the discipline they are teaching. A writing test offers a way out of this dilemma by shifting the responsibility for dealing with writing skills from the individual university teacher marking the latest batch of essays or tests. As one professor remarked to me of a third-year student in his political science class: "He's got this far, and I don't see that I can fail him now just because of his writing, but I don't really think he should have been allowed to get this far." There seems little justification for predicting that students will be unable to cope with university studies if their writing skills are poor. Insisting that students provide a separate 
demonstration of their proficiency in writing appears to be worthwhile only if universities believe simply that their graduates should be able to write with an acceptable level of competence - whether or not they can sometimes complete academic requirements without being able to do so.

On similar grounds we must question the assumption that improving writing skill sufficiently to pass a writing test will be easier for a student who writes poorly than making whatever special accommodations and adjustments are required to get through a university degree program. Students who are poor writers certainly do not seem to regard compulsory writing tests as doing them a favour. They are likely to have been aware of their difficulties with writing for several years, and to be skeptical about the possibility of radically improving their skill in writing after several years of schooling in which teachers have tried to help them do so. They seem to prefer to manipulate their course and program options, to choose courses and degree programs which do not require much formal writing, to avoid certain teachers, and to withdraw from courses that turn out to be unmanageable. When faced with an academic requirement that cannot be got around they may seek help from friends or resign themselves to a poor grade in a particular activity involving writing, hoping to avoid failure by a strong showing in other aspects of the course. Instructors sometimes declare that to show how serious they are about the quality of writing in the essays they are assigning they are devoting a certain proportion of the mark to written expression. This is, however, arguably a benefit to poor writers, since such a procedure limits the extent to which their scores will be affected by deficiencies in expression. They can be reasonably confident that the whole essay will not be rejected on the basis of the quality of the writing. Hall and Carlton (1977) found that almost without exception the Ontario university students they interviewed criticized the training they had received in writing, but the authors went on to comment:

Most of the students have discovered that their deficiencies are not an insuperable barrier to postsecondary education. They have discovered ways of ignoring large parts of assigned readings, and of substituting oral communication for written work. They find that postsecondary teachers have adapted to their deficiencies; that they accept point form comments in place of sentences, that they minimize the amount of writing required, and they generate teaching procedures and methods of examination that do not require either sophisticated reading skills or minimal writing skills. (pp. 38-39)

The further assumption which seems to underlie the usual rationale for the university writing tests is that almost all the students whose writing is initially found to be deficient will be able to meet the required standard within a reasonably short time. If this were not assumed, it is unlikely that the universities which have tests would have agreed to institute them, since a considerable loss of students might be anticipated. However, a survey by Krashen (1984) of the meagre research on the effectiveness of college-level instruction in writing suggests only that there is some evidence that the most general and obvious features of form and organization may be teachable at this comparatively late stage in a person's 
education. Krashen concludes that neither correction of errors in completed essays nor "grammar instruction" have much impact, and he extrapolates persuasively from his work on second language acquisition to argue that the most significant factor in the development of writing skills is not the instruction received by students but the reading they do. Improvement by this route is likely to be a long-term process. A meta-analysis of studies of composition teaching in schools by Hillocks (1984), on the other hand, concludes that there are some methods which may be generally effective, although the methods most commonly employed, including instruction in grammar, are probably not very useful. Overall there seems to be a dearth of evidence for the effectiveness of the kind of remedial instruction on which many postsecondary institutions in North America spend a great deal of time and money. In view of the legendary intractability of college and university students' difficulties with writing one is tempted to concur with what seems to be the general perception of remedial English teachers - that for most students the improvements at this age level are distinctly marginal.

And yet the Ontario universities which have writing proficiency tests report that the vast majority of students who initially fail their tests eventually fulfill the requirements. On looking in detail at the procedures involved, however, one is tempted to the speculation that the tests may be successful only in making the problem appear to go away. At some universities which have writing tests, for instance, students can evade the testing procedure eventually by passing a special remedial course. This introduces a number of possible contaminating factors, such as the tendency for the distribution of marks to change in a remedial group (so that a relatively poor writer now looks quite good) and the likely boosting effect on grades of basing a significant proportion of the assessment on writing which is not done under test conditions. In addition, teachers awarding marks in such courses find-themselves involved in a conflict of interest, since they have a natural desire to demonstrate that their teaching is effective. At some universities the tutors who patiently coach students preparing to rewrite the test are also the people who mark it. One doesn't have to be a cynic to see a problem here, especially in view of the severe reliability problems endemic to essay test scoring (Breland, 1983), and the further difficulty of maintaining consistent standards from one year to another. In her survey of Canadian universities with writing tests, Drain (1984) found that statements about expected standards were, not surprisingly, couched in "vague or subjective" terms. Failure rates at all the universities which have been testing for some years have undergone sharp movements or steady drifts downwards, for reasons that in most cases are not clear. The University of Waterloo failed more than $40 \%$ of its students in the first two years of its test, but the failure rate has gradually declined to a current figure of about $8 \%$. At one university in September 1986 an unexpectedly high failure rate was brought into line with that of previous years by the re-reading of the essays in about two hundred marginal papers. The eventual success of students who initially fail a writing test may owe more to looseness and slippage in the system than to genuine improvements in writing ability. The use of essay test procedures which have a distinctly dubious 
reliability, and the provision of alternative routes to satisfying the requirement through remedial courses, may mean that the universities never have to face squarely the question of whether or not most poor writers can significantly increase their level of performance in writing through short-term remedial work at the university level.

If the ostensible purposes of the tests and the ways in which they work in practice are questionable, however, the concern from which they spring seems straightforward. The criticisms of student writing skills expressed so frequently in the late seventies have not disappeared, though there may be less optimism in the universities about the possibility of improving the situation. There appears to be still a general agreement among university teachers that graduates ought to be able to write fairly clearly and correctly, and an equal degree of agreement that a disconcerting number of their students cannot do so even when expressing relatively uncomplicated ideas. This emphasis on the importance of writing seems easily defensible in theory. The formulation, development and transmission of ideas and knowledge require the making of careful distinctions between statements on the basis of their relative degrees of clarity, accuracy and precision. Writing, which formalises and crystallises these procedures, is therefore a central activity in learning at the university level. The universities' historic role has been to provide the societies they serve with a pool of manpower able to perform those functions for which a high degree of theoretical understanding of certain phenomena is required. The usefulness of the education they offer is reduced and its purpose to some extent frustrated if graduates cannot use language clearly to discuss complex subjects. The universities feel a responsibility to certify levels of competence in such matters in their graduates, and to exercise quality control in an area which both employers and the general public claim to consider important. Few people, 1 imagine, would object to this, even though ours is a society in which most people do very little writing, in which many people have successful careers without being able to write well, and in which graduates of many university programs can in practice often profitably use their expertise even if they are poor writers.

The controversy surrounding McMaster's writing test in the fall of 1986 , however, and in particular the objections raised by representatives of the school system in their informal contacts with the university, suggested that on the subject of testing and standards of achievement the philosophical gap between the secondary school and university systems in Ontario has become wide. The current emphasis in Ontario schools on providing various forms of special education appears to be representative of a wider and pervasive attitude which might be somewhat speculatively summarized as follows. The most important task of the schools is to facilitate the educational and social advancement of all students. Giving students failing or even very low marks, except as a consequence of their non-participation in this endeavour, is counter-productive. If a student has not mastered something adequately, at whatever stage, the school's responsibility is to find out what the problem is and attempt to overcome it, providing whatever special help is necessary for those who do not succeed in normal ways. Marks will 
in some cases attempt to rank students in order of achievement, but they should not be used to draw a line which would stigmatize the less capable. This approach, admirable in many ways though it is, is difficult to reconcile with a commitment to maintaining traditional standards of achievement, and teachers who espouse it are unlikely to welcome any university writing test unless it is used simply to diagnose individual weaknesses and direct students to appropriate sources of help.

The writing tests introduced by a small number of Ontario universities over the last ten or so years can perhaps be seen as piecemeal attempts to take a limited stand against the philosophy that now seems to dominate the schools and in favour of a more traditional emphasis on standards of achievement, at a time when the larger question of university admission policies as a whole has been characterized by hesitation and uncertainty. The results are hard to assess, but it seems unlikely that the desire to graduate only students who can write as well as the universities would like is compatible with the universities' willingness to accept as many students as they do. This basic contradiction underlies the patchwork of compromises which a scrutiny of the test procedures reveals. The writing proficiency tests discussed here appear to be an attempt to find a middle ground between two possible extreme positions which the universities might adopt in response to the concern about writing standards. At one extreme it might be argued that in degree programs in which writing ability is considered crucial the universities should be insisting on a demonstration of real competence in writing, and for that matter in reading, whether or not this leads them to deny a particular educational opportunity to people who in other respects appear to be qualified, and whatever the impact on enrolment. Furthermore, since we have little reason for assuming that this competence can be acquired in a short time, if at all, by adults who don't possess it, and since in any case the universities are reluctant to take on the necessary remedial work even if it can be done, the demonstration of competence in writing should be a requirement for admission to these university programs. At the other of the two extremes it might be argued that the universities have for a long time knowingly accepted and graduated students who do not meet desired standards in writing, and that it is far from clear that this represents a real problem either before or after graduation. In addition, under the current funding system no university is likely to impose admission requirements which would result in the loss of a significant number of students. The universities, according to this view, should therefore put up with things as they are and offer students whatever remedial help they can. The present situation in Ontario, with a minority of universities operating a variety of test schemes of dubious effectiveness, while some of the other universities wonder from time to time whether to join in, nicely reflects the ambiguity of the universities' position on the whole question of standards and admission requirements over the last twenty years.

\section{REFERENCES}

Breland, H.M. (1983) The direct assessment of writing skill: A measurement review. New York: College Entrance Examination Board. 
Building an educated society, 1816-1966. (1966) (Statement by the Hon. William G. Davis, Minister of Education, to the Legislative Assembly of Ontario. June 1966). Toronto: Department of Education.

D'Oyley, V.R. and Müller-Solger, H. (1975) National testing for college and university (SACU) in Canadian higher education. International Review of Education, 21. 91-109.

Drain, S. (1984) Report of a survey of writing competency testing in Canadian universities in 1984. Paper presented to the annual meeting of the Association of Canadian University Teachers of English, July 1984.

Elliott, H.A. (1971) SACU and the SACU tests: Past, present and future. School Guidance Worker. $26,6-11$.

English language proficiency program: general information. University of Waterloo.

Fleck, P. (1976) The need for "remedial English" in universities. Association of Canadian University Teachers of English

Fleming, W.G. (1959) Personal and academic factors as predictors of first year success in Ontario universities. Atkinson Study of Utilization of Student Resources. report no. 5. Toronto: University of Toronto.

Fleming, W.G. (1965) Characteristics and achievement of students in Ontario universities. Atkinson Study of Utilization of Student Resources, report no. 11. Toronto: OISE.

Hall, O. and Carlton, R. (1977) Basic skills at school and work. Toronto: Ontario Economic Council.

Hillocks, G. (1984) What works in teaching composition: A meta-analysis of experimental treatment studies. American Journal of Education, 93, 133-170.

Khan, S.B., Ransom, P., and Herbert, M. (1970) The prediction of first-year success in Ontario universities. Toronto: OISE.

Khan, S.B., and Rickard, S.A. (1971) The prediction of university achievement in Ontario universities, 1969-70. Toronto: OISE.

Krashen, S.D. (1984) Writing: Research, theory and applications. Oxford: Pergamon.

Norman, C. (1976) The Queen's English. Department of English, Queen's University.

Northey, M. and Evans, P. (1983) Final report: College Diagnostic Writing Test. Association of Colleges of Applied Arts and Technology of Ontario.

Notes toward a history of the English Language Proficiency Program, first year: 1976-77. (1977) Faculty of Arts, University of Waterloo.

Palmer, D. (1987) Multiple-choice tests of writing: Should teachers dislike them so much? Indirections, 12, 7-16.

Priestley, F.E.L., and Kerpneck, H.I. (1976) On undergraduate studies in English in Canadian universities. Association of Canadian University Teachers of English.

Ontario Test of English Achievement: The final report on its development. (1983) Toronto: Council of Ontario Universities.

Report of the Grade 13 Study Committee, 1964. (1964) Toronto: Department of Education.

Secondary/postsecondary interface study. (1976) Toronto: Ministry of Education and Ministry of Colleges and Universities.

Watson, C., and Quazi, S. (1969) Ontario university and college enrollment projections to 1981/2: 1968 projections. Toronto: OISE. 